\title{
The Involvement in Czech and Slovak Pop Music after November 1989
}

\section{Zuzana Zemanová}

The Encyclopedia of Jazz and Popular Music, published in 1980, explains an involved song as the synonym of a political song and dedicates several pages to this topic. ${ }^{1}$ This shows the weight which this type of song had before November 1989. The communist regime became aware of the huge impact of popular music as well as its potential to influence the opinions and the behaviour of Czechoslovak citizens. Along with this, some festivals focusing on this action were held and supported by the communist regime (the Festival of Political Songs in Sokolov, in the Czech Republic, and in Martin, in Slovakia). The involvement appeared in many different forms: in political issues, but more often in social ones. The topics of those songs were meant to point out the negative phenomena in society and the bad habits of the public (alcoholism, reckless driving, vandalism) or on the other hand to praise the bright side of society as the best way to maintain socialism (supporting appropriate jobs, e.g. doctors, drivers of public transport). These kinds of songs represented a bearable compromise for the professional bands and singers on how to be involved and to avoid political issues at the same time. The authors in the unofficial scene expressed quite a contrary form of involvement - they conveyed the artists' opinions of the governing ideology and the problems of common days.

After 1989, the term involvement gained a rather negative connotation not only in popular music. The rapid social development reflected in lyrics and in literature in a very similar way. Pavel Janoušek was thinking about the function of the literary texts of those days:

High-quality art and literature is a strange thing. Proud of its own peculiarity, it refused to serve the politics and politicians, yet it concurrently "fights" for harmony in lives of individuals and the social life as well. The literature longs for an ideal world but at the same time it becomes more important in direct proportion to

${ }^{1}$ Antonín, Matzner, Ivan Poledňák, and Igor Wasserberger, eds., Encyklopedie jazzu a modernípopulární hudby, věcná část (Praha: Supraphon, 1980), 308-310. 
the social ills which it opposes. [...] When the literature meets its social enemy it gets its value, the content, the topic and the aim. ${ }^{2}$

In brief: literature which has no function to fight or to form something lacked social significance. Many lyricists - as well as the writers - seemingly couldn't handle that newly acquired freedom and they had problems finding any inspiring topics. Others acclaimed the "restoration of chaos" and concluded that neither literature nor lyrics should substitute political discussion and journalism. And, finally had finally arrived an era wherein society would free itself from the strong and strongly outdated belief that literature - actually songs - should guide and form the recipient. Soon after the end of the revolutionary excitement it was proven that it is not possible to find distance from political and social life. A new period brought new problems which could be dealt with by means of literature and lyrics. For the purpose of this study, involvement is understood very broadly. An involved song can be any song that meets society and expresses the ideas of the current affairs without any explicit urge.

Karel Kryl, one of the iconic protest song writers of the era before 1989, publicly expressed his disagreement with dividing up Czechoslovakia and also showed his disappointment in the development of the situation after November 1989 ("it is true that revolutions feed on their own children but it is even worse when the children feed on their own revolution") $)^{3}$. Kryl didn't influence the form of Czech popular music after 1989 too much - listeners preferred new genres, foreign production, and entertainment. In 1994, when this era formed a critical response to the new attitudes, Kryl died. He is example of the continuity of production before 1989 . Now, the subject of our attention will be mainly rock and pop songs, also partly hip hop songs, and the field which can be called pop-rock song writing (the combination of electric instruments and an emphasis on lyrics).

The band Kabát has been working on their socially critical repertoire since the beginning of the 1990s. They committed themselves to economic criminality, the inflow of foreign funds or the issue of corruption and they have done so in such an amusing way. For example in one of their favourite songs is called "Colorado", wherein the band parodies the so-called American dream in a story about a cowboy who leads an easy-going life in the Czech Republic and who takes advantage of barely enforced laws, like in the Wild West. This melodic song hit the charts but many listeners did not realize its critical point of view. The disillusioned song "Země plná trpaslíkư" [The Country Full of Garden Gnomes] can be seen as

\footnotetext{
2 Pavel Janoušek, “Time-Out aneb Zhroucená tradice,” Tvar 1, no. 43 (1990): 3.

3 Karel Kryl, Pưlkacír (Praha: Rozmluvy, 2009), 218.

${ }^{4}$ Kabát, Colorado, Praha: Monitor-EMI, 1994.

5 Kabát, Země plná trpasliki̊, Praha: Monitor-EMI, 1995.
} 
its opposite: on one level, it reflects a boom of products up for mass sale, which spread mainly near the borders. In the second level, the song is more serious and expresses the fear of becoming little gnomes who can be sold to anyone.

The song called "Neděkujem, vypadněte" [Thanks for nothing, get out of here] by band Wanastowi Vjecy (2000) was a strong protest song. It came as a rude response to the initiative called "Thank you, go away" which emerged from the $10^{\text {th }}$ anniversary of the fall of totalitarianism in November 1999. The aim of this initiative was to make the supreme politicians engage in some kind of a moral reflection. Wanastowi Vjecy approached the problem more insistently and in more provoking way. Although this is not their typical work, it is evident that they were not so serious, they acted with humour and they are also self-abasing.

We can also see involvement in the reflection of everyday life. This includes, for example, the lyrics of the 1990s hip hop band Chaozz. They drew inspiration from a very wide field of topics - from AIDS warnings, to a critique of police methods, towards the most popular song "Televize" [Television] ${ }^{6}$. It was devoted to a newly emerging phenomenon of commercial mass media. It was a satire of TV programmes which are no longer remembered these days. Nowadays, listeners can thus realize the transience of celebrities and fame in media in general. In spite of the fact that the song was aimed at ridiculing one particular TV production, it hit the charts and became famous on the same TV channel. This is a common principle which occurs in commercial mass media. A reasonable critique can be acceptable when it comes to the ratings and a profit. This is a fundamental difference in contrast to totalitarian mass media which forbade everything considered to be risky.

All previous features of social critique aimed at political, economic and media power. A critical view of ordinary people has emerged since the turn of the century. Especially the theme of how to deal with the newly acquired freedom. In the song "Marx Engels Beatles" the band Vltava sings "I am waiting in Bohemia / and life is close to me / my life with a full bowl is really close." ${ }^{7}$ The lyrics comment on feelings of people who lived their young lives formed by totalitarianism and who had problems orientating themselves in society after the Velvet Revolution. They follow their dreams about a better future but they seem to be still only waiting for it. The Beatles join the imaginary rhythm of Marx and Engels in the chorus. Although the contribution of the Beatles is indisputable, they too represent something which no longer exists. We can stay calm and

${ }^{6}$ Chaozz, ... a nastal chaos, Praha: PolyGram, 1996.

7 Vltava, Marx Engels Beatles, Praha: Bonton, 1998. 
believe in yesterday with their most popular song combined with a quotation from The Internationale ("let Yesterday sound from the throat of the ground").

Czech pop song writer Xindl X (real name Ondřej Ládek) very intensively concentrates on the issue of freedom. While Xindl's songs, which are usually played on the radio, are based on self-reflection and puns, his album Čecháček made [Made by a Little Czech] ${ }^{9}$ is highly satirical and critical. It is evident from the name of the song that the author deals with the issue of being a "little Czech" in the sense of narrow-mindedness, envy, passivity and self-pity. The title song "Čecháček a totáček" [The Little Czech and the Totalitarian] focuses on nostalgia for a time of egalitarianism and strict limits, which didn't provide any choice but on the other hand didn't cause any delusion at all. In other songs from the same album Xindl X mentions problems with corruption connected to money, or as a way of controlling people. He also analyses the cause of spreading neo-Nazism and other ideologies among the youth - longing for unity, tendency to accept other people's ideas and the sense of security resulting from collective self-confidence (song "Naše parta" - Our Team).

I consider the song "Já a dábel" [Me and the Devil] the best song of this album. It gives the evidence of the difficulty of defending against evil. We are conscious of its existence and we try to avoid it, while at the same time we find it attractive, it can give us advantages and make our lives better. Thus, we give in and convince ourselves that there is nothing bad and that everything is under our control. We can apply this to various situations - such as drugs, trust in ideologies, deceits and small lies and an alibistic detraction of our own attitudes ("I am not a racist but...", "I am not biased against homosexuals but...").

In spite of his harsh poetics and connection to pop, Xindl X is rather of folk origin. The lyricist and the singer Radoslav Banga, known under his pseudonym Gipsy.cz, draws his inspiration from a completely different resource. He merges the hip hop genre with gypsy music. He shows his ability to morph serious topics such as racism into humorous lyrics. His song "Barvoslepej svět" [Colour-blind World ${ }^{10}$ hyperbolically explains that the terms "black" and "white" aren't accurate because nobody can be entirely black or white. Therefore, the criterion of the colour of the skin is irrelevant and very relative. The Czech sees the gypsy as "black" because his skin is one shade darker. But, a black person considers a gypsy to be a white man. "It is kind of a paradox being black at 3 o'clock but turn white again at 2 past 3 ," says the main character doctor Ladislav Kolór who treats people for "widespread disease called colour blindness". People of all races

\footnotetext{
${ }^{8}$ Allusion to the Czech version of The Internationale: "[...] now the law thunders ominously in the throat of the ground [...]."

${ }^{9}$ Xindl X, Čechácék made, Praha: Universal Music, 2014.

${ }^{10}$ Gipsy.cz, Reprezent, Dolní Loučky: Indies Scope Records, 2008.
} 
come to his surgery. It means that racism isn't only one-sided view (the Czechs versus the gypsies) but it comes to us in many different ways. Lyrics by Gipsy. $\mathrm{cz}$ also comment on the danger of drug addiction, unsafe sex and they also deal with the life in ghetto, etc.

Many lyricists who are afraid of Islamic extremists or the endangerment of Czech sovereignty have recently started to write songs. They have used similar means of art. In most cases, the authors stick to concerns, risks and they rouse citizens (e.g. Vilém Čok, Olivie Žižková, and others). Jaromír Nohavica is an exception. He tried to keep this burning issue in perspective. He used the romantic melody from the French film Muž a žena [Man and Woman] (1966) and transformed the lyrics into a parody in which he fights an uninvited stranger ("The Arab is dating my wife / I think I will end his life"). ${ }^{11}$

The band Ortel from Plzeň, with their front man Tomáš Ortel (real name Tomáš Hnídek), became very much discussed. His fans like him for being a patriot, a defender of truth and they follow him as a moral hero. The opponents label his songs as racist, xenophobic and nationalistic. In fact, his lyrics often call upon violence, hatred and especially the destruction of existing economic and political structures. When it comes to different ethnicities, Ortel makes sure not to cross the line set by law. Although his aversion to foreigners and minorities is ostentatious, he never uses racial slurs in his official works.

There is no place for humour or self-irony in his lyrics. Everything is meant to be serious. The word stock is based on key words - home, homeland, family. $\mathrm{He}$ often refers to traditions, ancestors and their fight for state sovereignty. In response to critics, Ortel presents himself as a victimized person who was forbidden to sing because he "told the truth". Unlike Xindl X, Ortel supports the listeners' point of view that everything bad comes from higher-up - politicians and easily manipulated mass media - whereas the ordinary people are only helpless victims condemned to live in poverty and distress. Ortel's aim is to bring about respect and popularity. For this purpose, he uses literary expressions and elements of traditional poetry (rhymed structure) combined with spoken language. He uses vulgarisms to such an extent that doesn't shock the listeners but only catches their attention.

The band is strongly supported by listeners. Evidence of this is that they were placed in the well-known poll "Český slavík", which is rather a conservative music competition. I think it is necessary to continue to critically analyze Ortel's lyrics and to show that their sheer populism doesn't offer any solutions (for Ortel, the

${ }^{11}$ Jaromír Nohavica, Baraba mi šahá na babu, August 18, 2016, https://www.youtube.com/ watch?v=DtZjR3vvbX4 
only possible solution would be in a violent revolution), instead of banning him or awkwardly looking the other way.

The other side of involvement can be seen in the band Živé kvety. "How lucky we Czechs are to have the Slovak band Živé kvety. It is one of the bands which shows us that rock'n'roll is worthy," says Ondřej Bezr. ${ }^{12}$ He points out that this genre is missing a band with such an explicit point of view. They even perform more in the Czech Republic than in Slovakia. This might indicate the fact that Czech society is more liberal than Slovaks and therefore the Czechs are more likely to accept the ideas presented in the songs. The art manager of Živé kvety, the singer and lyricist Lucia Piussi, feels like she has lived in her homeland among people who align themselves with minority ideas. She feels akin to a dissident from the era before November $1989 .{ }^{13}$ Although the band prefers other musical influences, they rank among the Czech underground, particularly I. M. Jirous. This is not by chance.

The band shows involvement in many different ways on its last album Nové poschodia [The New Floors] which was released in 2016. In the long term, Živé kvety oppose xenophobia, nationalism and they also comment on particular public affairs, racist attacks, and so on. As noted above, this attitude isn't so strange in the Czech Republic but more courage is needed in Slovakia. Piussi clearly expresses her opinion on the attitude of society towards the foreigners in the lyrics "To, čo nás spája” [That Which Joins Us Together]: "That what joins us together / is stronger that what separates us. / You will never teach me to hate that black, strange / to believe in the illusion of the rabble who say that evil is in the others / that God created not only man but two kinds of human beings / and that you are of the one who always wins, you fool / never."14

Živé kvety also comment on the topic of cities, Bratislava in particular. They critically interpret the privatization of public areas and commercial urban development which happens without any prior consideration and with silent agreement from politicians. The picture on the $\mathrm{CD}$ cover which shows the Bratislava castle in a shape of a bizarre Babylon tower in danger of falling down, illustrating well the interconnected themes of overgrown nationalism and urbanistic bad taste. In general, Živé kvety are typical for their interest in social issues, especially regarding interpersonal relationships and the connection to particular places where we live. The critique of government officials appears often as well but, unlike Ortel's attitude, it doesn't call upon their destruction. It has been only

12 Ondřej Bezr, “Živé kvety natočily ‘pomalé’ album, ale nerezignují,”January 24, 2013, http://kultura. zpravy.idnes.cz/recenze-zive-kvety-0al-/hudba.aspx?c=A130124_093611_hudba_ob

${ }_{13}$ Antonín Kocábek, "Jsme takoví stř̌edoevropští bastardi," Magazín UNI 26, no. 9 (2016), http:// magazinuni.cz/hudba/jsme-takovi-stredoevropsti-bastardi/

14 Żivé kvety, Nové poschodia, Bratislava: Slnko records, 2016. 
a bitter statement amplified by Slovakia's bad experience with the authoritarian regime of Vladimír Mečiar, in 1990s.

It is evident from the given examples that involvement in Czech and Slovak contemporary pop music is a wide topic and its conception is still in progress. The reflection on post-revolutionary circumstances, political culture and economic criminality occurring in the 1990s were dominant, while from the turn of the millennium it came out that people weren't used to freedom in such an extent, so the issue of dealing with freedom expanded. The opinions have clearly intensified. Xindl X or Gipsy.cz don't point to only those in higher places but also to the disregarding, passivity or alibi of impartial citizens, including themselves as well. Ortel blames "the others" - politicians and representatives of economic power and he provides a relief from people's own responsibility. The gap between these artists' points of view corresponds to the noticeable division of opinions in society which can be seen nowadays.

\section{The Involvement in Czech and Slovak Pop Music after November 1989}

Abstract

This contribution pursues the manifestation of social involvement in the lyrics of various genres of pop music after 1989. Any content which touches upon the life of the society or the particular social phenomenon and expresses the specific opinion of it can be considered and broadly understood as "involved". The contribution follows the development of the thematic structure of the lyrics from the 90's (e.g. post-revolutionary disillusionment, corruption and economic criminality) until the New Millenium (racism and xenophobia, nationalism, "memory loss", etc.). The subject of the detailed analysis is especially the work of the era after 2010 when the opinions which have been presented in the lyrics have highly reflected the opinion differences of the society (Xindl X, Gipsy.cz, Živé kvety, etc. versus e.g. Ortel).

\section{Angažovanost $v$ české a slovenské pop music v období po listopadu 1989}

\section{Abstrakt}

Studie sleduje projevy sociální angažovanosti v písňových textech různých umělců populární hudby po roce 1989. Jakýkoliv obsah, který se dotýká života společnosti, 
respektive konkrétního společenského fenoménu, a který vyjadřuje specifický názor, může být v širším smyslu chápán jako „angažovaný“. Příspěvek sleduje vývoj tematického zaměření písňových textů od devadesátých let (kupř. postrevoluční deziluze, korupce a ekonomická kriminalita) až do nového tisíciletí (rasismus, xenofobie, nacionalismus, „ztráta paměti“ atp.). Tematické analýze je podrobena zejména tvorba $z$ doby po roce 2010 , kdy literární obsah písní významným způsobem reflektoval rozdílné názorové trendy společnosti (Xindl X, Gipsy.cz, Zivé kvety a další versus např. Ortel).

\section{Keywords}

Czech Republic; Slovakia; popular music; involvement; thematic analysis

\section{Klíčová slova}

Česko; Slovensko; populární hudba; angažované texty; tematická analýza

\section{Zuzana Zemanová}

Department of Czech Studies

Faculty of Arts, Palacký University

Kř́ǐzovského 10, 77180 Olomouc, Czech Republic

zuzana.zemanova@upol.cz 